\title{
Survey Kesadaran Masyarakat dalam Meningkatkan Kesehatan Fisik di Masa Pandemi
}

\section{Public Awareness Survey In Improving Physical Health During a Pandemic}

\author{
Veny Juniarni Hardi ${ }^{1}$, Dedi Supriadi ${ }^{2}$, Andy Supriady ${ }^{3}$, Vicki Ahmad \\ Karisman $^{4}$ \\ 1,2,3 Program studiPJKR, STKIP Pasundan, Jalan Permana No. 32B Kota Cimahi, Jawa Barat, \\ 40553, Indonesia
}

\begin{abstract}
Abstrak
Pandemi Covid 19 pada tahun 2020 membawa banyak perubahan dalam kehidupan masyarakat, semua hal harus dilakukan di rumah, belajar berkerja, beribadah bahkan berolahraga di lakukan dirumah. Rumusan masalah penelitian ini tentang Kesadaran masyarakat dalam mneingkatkan kesehatan dimasa pandemi, apabila kesadaran masyarakat dalam menjaga kesehatan meningkat maka akan menciptakan pola hidup sehat bagi tubuh dan lingkungan nya bahkan besar kemungkinan akan terhindar dari virus yang dapay membahayakan bagi tubuh. Tujuan penelitian ini adalah mengetahui tingkat kesadaran masyarakat dalam meningkatkan kesehatan dimasa pandemi. Penelitian ini merupakan penelitian desktiftif kuantitatif dengan metode survey. Populasi dalam penelitian ini 42 orang partisipan penelitian ini 12, Teknik sampling insidential sampling. Instrumen penelitian menggunakan angket melalui googleform. Hasil dari penelitian ini adalah kesadaran masyarakat dalam meningkatkan kesehatan dimasa pandemi meningkat, masyarakat menyadari arti pentingnya menjaga kesehatan dan melakuka pola hidup sehat untuk individu dan lingkungan sekitar.
\end{abstract}

Keywords: Kesadarean dan kesehatan, Covid 19

\begin{abstract}
The Covid 19 Pandemic in 2020 brought about a lot of change in society's life, all things to do at home, learn to work, serve even practice at home. This series of research problems about public awareness in raising health where the pandemic, when the public's awareness of health is increasing, will create a healthy lifestyle for the body and its environment even more likely to be avoided from viruses that could be harmful to the body. The aim of this research is to know the level of public awareness in improving health in the pandemic. This study is a quantitative descriptive study. The research tool uses an angle through googleform. The result of this research is the public's awareness of improving health where the pandemic increases, the public's awareness of the importance of maintaining health and performing healthy lifestyles for individuals and the environment.
\end{abstract}

Keywords: Consciousness and health, Covid 19 


\section{PENDAHULUAN}

Konsep kesehatan penting untuk membantu memberikan kesadaran kepada masyarakat tentang arti pentingnya kesehatan yang menyeluruh. Kesadaran kesehatan (health consciousness, HS) adalah suatu kepedulian dan perhatian untuk menjadi lebih baik dan termotivasi dalam memperbaiki, mempertahankan, menjaga kesehatan dan kualitas hidup dengan menerapkan pola hidup sehat. (Kutresnaningdian \& Albari, 2012). Orang yang memilih jalan hidup yang serba mudah dan tidak teratur dalam jangka panjang akan menjadikan orang tersebut menjadi tidak sehat, pemalas dan kehilangan jati diri karena hidupnya tidak disiplin dan tidak mampu mengendalikan diri.("Kebiasaan Berperilaku Hidup Sehat Dan Nilai-Nilai Pendidikan Karakter," 2012) . Tanpa kesehatan manusia akan mengalami hambatan dan mengalami penurunan kondisi fisik. Kesehatan adalah keadaan seimbang yang dinamis, dipengaruhi faktor genetik, lingkungan dan pola hidup sehari-hari seperti makan, minum, seks, kerja, istirahat, hingga pengelolaan kehidupan emosional.(Pane, 2015).

Pandemi COVID-19 pada tahun 2020 ini membawa banyak perubahan dalam kehidupan masyarakat. Semua harus dilakukan di rumah. Belajar, bekerja, beribadah, bahkan olahragapun dianjurkan di rumah. Sebenarnya olahraga bisa dilakukan di luar rumah maupun di dalam rumah. Namun, di masa pandemi corona, olahraga harus dilakukan dengan cermat dan dipertimbangkan dengan seksama. (Yuliana, 2020) Cara pencegahan yang paling sederhana yaitru dengan membiasakan diri mencuci tangan dengan sabun dan air mengalir. Masyarakat Indonesia saat ini masih kurang menyadari akan pentingnya hidup sehat. Hal ini terjadi karena kurangnya animo/minat dan apresiasi masyarakat terhadap olahraga. Partisipasi berolahraga penduduk perkotaan lebih tinggi apabila dibandingkan dengan penduduk perdesaan. Kondisi ini didukung oleh fasilitas dan jenis olahraga yang berkembang di perkotaan lebih banyak dibandingkan di perdesaan, (Brier, 2020).

Kesehatan masyarakat adalah ilmu dan seni memelihara, melindungi, dan meningkatkan kesehatan masyarakat melalui usaha-usaha masyarakat dalam pengadaan pelayanan kesehatan, pencegahan, dan pemberantasan penyakit. Kesehatan masyarakat mencakup semua kegiatan, baik langsung maupun tidak langsung, untuk mencegah penyakit (preventif), meningkatkan kesehatan (promotif), terapi (kuratif), maupun pemulihan (rehabilitatif). Pilar utama ilmu kesehatan masyarakat antara lain epidemiologi, biostatistik, kesehatan lingkungan, pendidikan kesehatan dan ilmu perilaku, administrasi kesehatan, gizi masyarakat, serta pelayanan kesehatan. (Surahman \& Supardi Sudibyo, 2016). Kesehatan masyarakat adalah sebagai aplikasi keterpaduan antara ilmu kedokteran, sanitasi, dan ilmu sosial dalam mencegah penyakit yang terjadi di masyarakat. (Erliana \& Sri, 2016). Kemudian tujuan dari Pembangunan kesehatan masyarakat yang merupakan salah satu upaya pembangunan nasional diarahkan guna 
tercapainya kesadaran, kemauan, dan kemampuan hidup sehat bagi setiap orang agar terwujud derajat kesehatan masyarakat yang optimal (Muttaqien, Sugiarto, \& Sarifudin, 2019).

Tujuan Kesehatan masyarakat baik dalam bidang promotif, preventif, kuratif dan rehabilitatif adalah tiap warga masyarakat dapat mencapai derajat kesehatan yang setingitinggi baik fisik, mental, sosial serta diharapkan berumur panjang. Adapun tujuan umum dan tujuan khusus kesehatan masyarakat adalah sebagai berikut: a. Umum: Meningkatkan derajat kesehatan dan kemampuan masyarakat secara menyeluruh dalam memelihara kesehatan untuk mencapai derajat kesehatan secara mandiri. b. Khusus: - Meningkatkan individu, keluarga, kelompok dan masyarakat dalam pemahaman tentang pengertian sehat sakit. - Meningkatkan kemampuan individu, keluarga kelompok dan masyarakat dalam mengatasi masalah kesehatan.(Erliana \& Sri, 2016). Kesadaran masyarakat lahir dari masyarakat itu sendiri yang lahir dari kebiasaan dalam masyarakat, dipengaruhi oleh lingkungan, peraturan-peraturan dan peranan pemerintahnya. (Muttaqien et al., 2019).

Secara konseptual, faktor-faktor yang mempengaruhi terhadap tumbuh dan berkembangnya kesadaran dapat didekati dengan beragam pendekatan disiplin ilmu. Menurut konsep proses pendidikan, partisipasi merupakan bentuk tanggapan atau responses atas rangsangan-rangsangan yang diberikan, yang dalam hal ini tanggapan merupakan fungsi dari manfaat (rewards) yang dapat diharapkan. Masyarakat adalah orang yang tinggal di daerah yang tedefinisikan secara geografis dan memiliki ikatan sosial serta psikologis dengan yang lain dan dengan tempat dimana mereka tinggal. (Brier, 2020).

Manfaat olahraga yang disampaikan oleh Daniel Landers, Profesor Pendidikan Olahraga dari Arizona State University: a. Meningkatkan Daya Tahan Tubuh Olahraga yang dilakukan dengan teratur, akan meningkatkan fungsi hormon-hormon dalam tubuh di mana hormon-hormon ini mampu meningkatkan daya tahan tubuh. b. Meningkatkan Fungsi Otak Keteraturan dalam berolahraga dapat membantu meningkatkan konsentrasi, kreativitas, dan kesehatan. Dengan olahraga, jumlah oksigen di dalam darah akan meningkat sehingga memperlancar aliran darah menuju otak. Sehingga meningkatkan fungsi otak. c. Mengurangi Stres Stres dapat terjadi pada siapa saja. Dengan olahraga, seseorang dapat dibantu untuk mengatasi emosi dan mengurangi kegelisahan sehingga mengurangi stres dalam dirinya. Bagi yang rutin melakukan olaharga memiliki tingkat kecemasan yang lebih rendah dibandingkan orang yang tidak berolahraga. Aktivitas olahraga menyebabkan tubuh bereaksi termasuk otak. Karena otak akan melepaskan banyak hormon termasuk endorphin yang bisa mempengaruhi suasana hati menjadi lebih gembira, riang dan senang menurunkan Kolesterol.

Ketika melkukan olahraga, tubuh bergerak dan membantu tubuh membakar kalori yang ada sehingga menghasilkan energi yang dibutuhkan tubuh untuk bekerja. Sehingga membantu 
tubuh mengurangi tertimbunnya lemak dalam tubuh. Olahraga yang teratur juga dapat membakar kolesterol LDL dan trigliserida serta meningkatkan kadar kolesterol baik (HDL). Hal ini sangat membantu tubuh tetap fit dan mengrangi resiko darah tinggi, stroke, kegemukan, dan penyakit jantung. (Pane, 2015).

Dengan demikian maka konsep dasar Kesehatan Olahraga adalah pembinaan mutu sumber daya manusia menuju sehat seutuhnya sesuai rumusan sehat Organissasi Kesehatan Dunia (World Health Organisation = WHO), melalui Pendidikan Jasmani, Olahraga dan Kesehatan, pelaksanaan Olahraga Kesehatan maupun Olahraga Prestasi, dan pelayanan Kesehatan Olahraga. (Giriwijoyo, Komariyah, \& Kartinah, 2007). Upaya kesehatan adalah setiap kegiatan untuk memelihara dan meningkatkan kesehatan yang bertujuan untuk mewujudkan derajat kesehatan yang optimal bagi masyarakat. Upaya kesehatan diselenggarakan dengan pendekatan pemeliharaan, peningkatan kesehatan (promotif), pencegahan penyakit (preventif), penyembuhan penyakit (kuratif), dan pemulihan kesehatan (rehabilitatif), yang dilaksanakan secara menyeluruh, terpadu, dan berkesinambungan. (Prasetyo, 2013),

Keterbatasan kita untuk bergerak terjadi ketika saat pandemi ini. Kita begitu berhati-hati supaya tidak ada transmisi virus padahal pergerakan tubuh sangat penting. Kita semua harus bergerak secara aktif, tidak memandang berapa usia kita. Saat berada dalam sutu posisi tertentu, duduk misalnya, harus ada waktu 3-5 menit untuk berdiri, berjalan dan melakukan peregangan. Aktivitas seperti ini akan membantu membuat otot lebih rileks, meningkatkan sirkulasi darah dan aktivitas otot (Wicaksono, 2020). Dalam menghadapi wabah Covid-19 ini, perlu adanya perubahan sikap dari setiap orang dalam hal menjaga kesehatan tubuhnya masing-masing. Selain berbagai cara yang dianjurkan untuk mencegah terjadinya penularan Covid-19, mengubah kebiasaan negative menjadi kebiasaan yang berdampak positif bagi dirinya sendiri sangat membantu dalam meminimalisir penularan wabah penyakit ini. (Dinda Mulyad, 2020). Salah satu diantara menerapkan pola hidup bersih dan sehat adalah melakukan aktivitas fisik, dengan melakukan aktivitas fisik yang tepat dan teratur maka kebugaran jasmani akan terbentuk (Ardiyanto, Purnamasari, Sukamto, \& Setianingsih, 2020).

Berkaitan dengan Kesadaran masyarat untuk meningkatkan kesehatan, maka peneliti akan mengkaji tentang kesadaran masyarakat di desa pangauban dalam meningkatkan kesehatan. Supaya terbentuknya masyarakat yang sehat dan terhindar dari berbagai virus yang mengancam. Bagaimana pun masyarakat paling tidak mengamankan dirinya, orang dekatnya, keluarganya, dan rekan-rekannya. Peneliti merasa tertarik untuk meneliti kesadaran masyarakat Desa Pangauban, karena kurangnya aktivitas menjaga kesehatan masyarakat saat ini. Terlebih dengan maraknya masyarakat yang lebih asik dengan ponselnya dibandingkan menjaga kondisi tubuh dan kesehatan dirinya sendiri. 


\section{METODE}

Penelitian ini menggunakan Metode penelitian deskriptif kuantitatif dengan metode Survey, penelitian deskriptif adalah penelitian yang bertujuan untuk menggambarkan keaadan, situasi,peristiwa dan lainya. Metode kuantitatif adalah metode penelitian yang digunakan untuk meneliti populasi atau sampel. Analisis data bersifat kuantitatif statistik. (Kutresnaningdian \& Albari, 2012). Penelitian kualitatif bertujuan mempertahankan bentuk dan isi perilaku manusia dan menganalisis kualitas-kualitasnya (Prasanti, 2018).

Penelitian survey mengatakan bahwa penelitian survey adalah "penelitian yang mengambil sampel dari satu populasi dan menggunakan kuesioner sebagai alat pengumpulan data yang pokok" (Heni Hendrawati, 2016). Pandemi COVID-19 yang sedang terjadi tidak memungkinkan pengambilan data secara langsung, sehingga diberikan kuesioner secara online.

Populasi adalah sebagai wilayah generalisasi yang terdiri atas: obyek/subyek yang mempunyai kualitas dan karateristik tertentu yang ditetapkan oleh peneliti untuk dipelajari dan kemudian ditarik kesimpulannya (Arikunto, 2011). Populasi pada penelitian ini adalah 42 warga masyarakat Kp Cibodas Rw 07 Desa Pangauban Kecamatan Batujajar Kabupaten Bandung Barat.

Sampel adalah bagian dari jumlah dan karakteristik yang dimiliki oleh populasi tersebut. Bila populasi besar, dan peneliti tidak mungkin mempelajari semua yang ada pada populasi, misalnya karena keterbatasan dana, waktu dan tenaga, maka peneliti dapat menggunakan sampel yang diambil dari populasi itu. (Sugiyono, 2014) partisipan yang digunakan yaitu 4 golongan masyarakat yang terdiri dari 3 orang anak-anak, 3 orang remaja, 3 orang dewasa dan 3 orang lansia dengan total sampel 12 orang.

Pengumpulan data pada penelitian ini ialah dengan menggunakan angket/kuesioner. Kesadaran Masyarakat dalam Meningkatkan Kesehatan Di desa pangauban Kecamatan batujajar Kabupaten Bandung Barat dengan menggunakan instrumen berupa kuesioner online melalui google form. 


\section{Tabel 1}

\section{Kisi - Kisi Instrumen Peneltian}

\begin{tabular}{|c|c|c|c|c|}
\hline \multirow[t]{2}{*}{ Variabel } & \multirow[t]{2}{*}{ Sub Variabel } & \multirow[t]{2}{*}{ Indikator } & \multicolumn{2}{|c|}{ No } \\
\hline & & & Positif & Negatif \\
\hline \multirow{6}{*}{$\begin{array}{c}\text { Membantu } \\
\text { memberikan } \\
\text { kesadaran kepada } \\
\text { masyarakat } \\
\text { tentang arti } \\
\text { pentingnya } \\
\text { kesehatan yang } \\
\text { menyeluruh. }\end{array}$} & \multirow{3}{*}{$\begin{array}{l}\text { Faktor } \\
\text { internal }\end{array}$} & Melakukan aktivitas fisik & $1,2,3$ & $19,20,21$ \\
\hline & & Mengonsumsi makanan bergizi & $4,5,6$ & $22,23,24$ \\
\hline & & Kurangi kebiasaan buruk & $7,8,9$ & $25,26,27$ \\
\hline & \multirow{3}{*}{$\begin{array}{c}\text { Faktor } \\
\text { eksternal }\end{array}$} & Membuat rutinitas & $10,11,12$ & $28,29,30$ \\
\hline & & Lebih bijak memilih informasi & $13,14,15$ & $31,32,33$ \\
\hline & & Menjaga komunikasi & $16,17,18$ & $34,35,36$ \\
\hline
\end{tabular}

Prosedur Penelitian yang digunakan dalam penelitian ini adalah dengan cara menganalisis kegiatan keseharian masyarakat di Desa Pangauban Kecamatan Batujajar Kabupaten Bandung Barat. Peneliti menyebarkan kuisioner online menggunakan google form kepada Masyarakat atau pemuda yang ada di wilayah Desa Pangauban. Adapun mekanisme pelaksanaan penelitian ini sebagai berikut:

1. Peneliti mencari data masyarakat Desa Pangauban Kecamatan Batuajajar kabupaten Bandung barat

2. Peneliti menentukan jumlah warga yang akan menjadi sampel penelitian

3. Peneliti menyebarkan kuesioner secara online melalui aplikasi whatsapp kepada responden.

4. Peneliti melakukan tabulasi data.

5. Peneliti melakukan proses pengolahan data dan analisis data secara deskruptif kuantitatif dalam bentuk presentase.

6. Peneliti mengambil kesimpulan dan saran.

\section{HASIL DAN PEMBAHASAN}

\section{Hasil}

Menghitung skor untuk setiap item dengan rekapitulasi pengumpulan data angket dari data 42 respondens berdasarkan data yang diperoleh dan menghitung data skor dengan jumlah skor tertinggi untuk semua item 74 x $1=74$ dan jumlah skor terendah adalah $45 \times 1=45$.

Setelah dipersentasekan maka nilai tersebut dimasukan kedalam kriteria perhitungan persentase sebagai berikut: 
Tabel 2

Frekuensi Kesadaran masyarakat dalam meningkatkan kesehatan dimasa pandemik

\begin{tabular}{|c|c|c|c|c|c|}
\hline & & Frekuensi & Persen & $\begin{array}{c}\text { Persen } \\
\text { Valid }\end{array}$ & Kumulatif Persen \\
\hline \multirow[t]{20}{*}{ Valid } & 45 & 2 & 4,8 & 4,8 & 4,8 \\
\hline & 48 & 3 & 7,1 & 7,1 & 11,9 \\
\hline & 49 & 1 & 2,4 & 2,4 & 14,3 \\
\hline & 50 & 1 & 2,4 & 2,4 & 16,7 \\
\hline & 51 & 3 & 7,1 & 7,1 & 23,8 \\
\hline & 52 & 4 & 9,5 & 9,5 & 33,3 \\
\hline & 53 & 3 & 7,1 & 7,1 & 40,5 \\
\hline & 54 & 2 & 4,8 & 4,8 & 45,2 \\
\hline & 55 & 3 & 7,1 & 7,1 & 52,4 \\
\hline & 56 & 5 & 11,9 & 11,9 & 64,3 \\
\hline & 57 & 4 & 9,5 & 9,5 & 73,8 \\
\hline & 58 & 3 & 7,1 & 7,1 & 81,0 \\
\hline & 59 & 1 & 2,4 & 2,4 & 83,3 \\
\hline & 60 & 2 & 4,8 & 4,8 & 88,1 \\
\hline & 61 & 1 & 2,4 & 2,4 & 90,5 \\
\hline & 62 & 1 & 2,4 & 2,4 & 92,9 \\
\hline & 69 & 1 & 2,4 & 2,4 & 95,2 \\
\hline & 72 & 1 & 2,4 & 2,4 & 97,6 \\
\hline & 74 & 1 & 2,4 & 2,4 & 100,0 \\
\hline & Total & 42 & 100,0 & 100,0 & \\
\hline
\end{tabular}

Tabel 3

Distribusi Bergolong Kesadaran masyarakat dalam meningkatkan kesehatan dimasa pandemik

\begin{tabular}{llll}
\hline No & Interval & Frekuensi & Persen (\%) \\
\hline $\mathbf{1}$ & $70-74$ & 2 & 4,8 \\
\hline $\mathbf{2}$ & $65-69$ & 1 & 2,4 \\
\hline $\mathbf{3}$ & $60-64$ & 4 & 9,5 \\
\hline $\mathbf{4}$ & $55-59$ & 16 & 38,1 \\
\hline $\mathbf{5}$ & $50-54$ & 13 & 31,0 \\
\hline $\mathbf{6}$ & $45-49$ & 6 & 14,3 \\
\hline & Jumlah & 42 & 100 \\
\hline
\end{tabular}


Berdasarkan tabel diatas, maka distribusi frekuensi bergolong kesadaran masyarakat dalam meningkatkan kesehatan dimasa pandemik dapat digambarkan dalam histogram sebagai berikut:

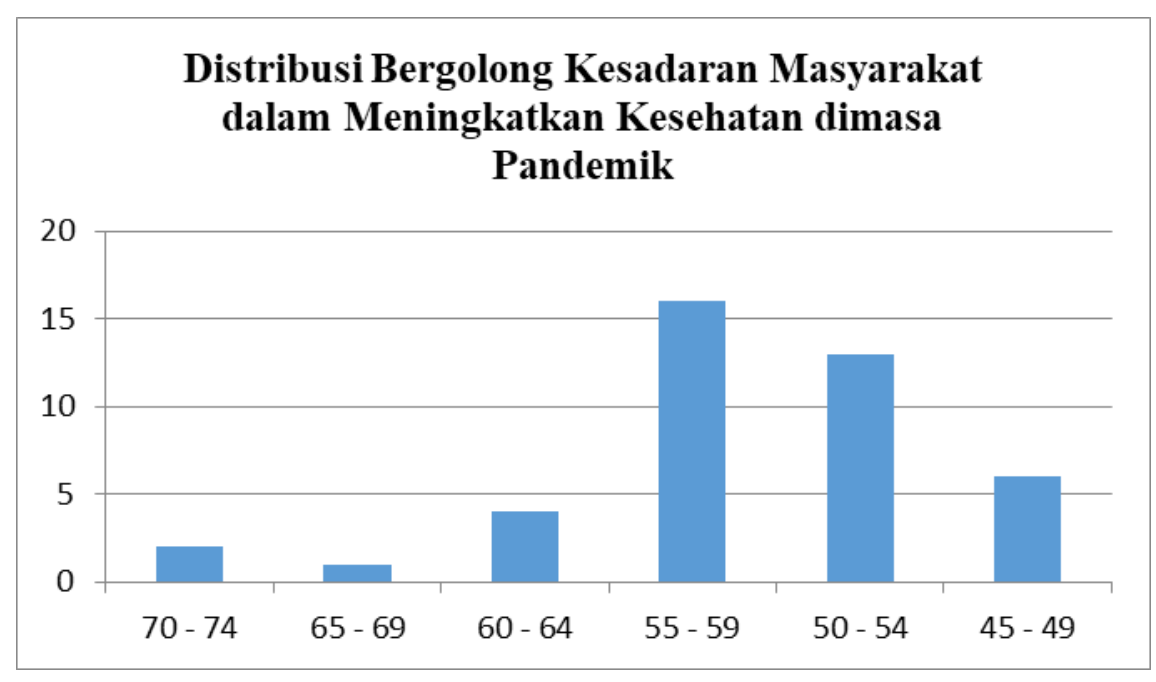

\section{Gambar 1}

Distribusi Bergolong Kesadaran Masyarakat dalam Meningkatkan Kesehatan dimasa Pandemi

Tabel dan histogram data Bergolong Kesadaran Masyarakat dalam Meningkatkan Kesehatan dimasa Pandemik di atas menunjukkan bahwa kelompok yang memiliki frekuensi terbesar terletak pada kelas interval 55 - 59 dengan jumlah frekuensi 16 . Kelompok yang memiliki frekuensi terkecil terletak pada kelas interval 65 - 69 dengan jumlah frekuensi 1 .

Data variabel penelitian kemudian digolongkan ke dalam kategori kecenderungan karakter kepemimpinan yang dapat diketahui menggunakan skor ideal. Skor ideal tersebut dapat menjadi tiga kategori kecenderungan, yaitu tinggi, sedang dan rendah (AZWAR, 2017). Kategori didasarkan pada standar deviasi dan skor rata-rata (mean). Penggolongan tersebut sebagai berikut:

Kategori Tinggi : Apabila $>\mathrm{M}+1 . \mathrm{SD}$

Kategori Sedang : Apabila $\mathrm{M}-1 . \mathrm{SD}$ sampai $\mathrm{M}+1 . \mathrm{SD}$

Kategori Rendah : Apabila $<\mathrm{M}-1 . \mathrm{SD}$

Berdasarkan kriteria diatas, maka diperoleh kategori karakter kepemimpinan yang tercantum dalam tabel berikut: 
Tabel 4

Distribusi Kesadaran Masyarakat dalam Meningkatkan Kesehatan dimasa Pandemik

\begin{tabular}{lllll}
\hline No & Rentang Skor & Frekuensi (F) & Persen $(\%)$ & Kategori \\
\hline $\mathbf{1}$ & $>61$ & 4 & 9,5 & Tinggi \\
\hline $\mathbf{2}$ & $49-61$ & 33 & 78,6 & Sedang \\
\hline $\mathbf{3}$ & $<49$ & 5 & 11.9 & Rendah \\
\hline Jumlah & 42 & 100 & \\
\hline
\end{tabular}

Kategori pada variabel dapat diartikan sebagai berikut: 1) Tinggi, berarti masyarakat memiliki kesadaran dalam meningkatkan kesehatan dimasa pandemi yang tinggi; 2) Sedang, berarti masyarakat memiliki kesadaran dalam meningkatkan kesehatan dimasa pandemi yang sedang; dan 3) Rendah, berarti masyarakat memiliki kesadaran dalam meningkatkan kesehatan dimasa pandemik yang rendah. Dari tabel 4.9 dapat terlihat bahwa 4 orang $(9,5 \%)$ tergolong dalam kategori tinggi, 33 orang $(78,6 \%)$ tergolong dalam kategori sedang, dan terdapat 5 orang $(11,9 \%)$ yang tergolong dalam kategori rendah. Dengan demikian dapat disimpulkan bahwa sebagian besar masyarakat di desa pangauban memiliki kesadaran dalam meningkatkan kesehatan dimasa pandemik sebesar $(78,6 \%)$. Sebaran data dari masing-masing kategori dapat dilihat pada gambar berikut:

\section{Pie Chart Kesadaran Masyarakat dalam Meningkatkan Kesehatan dimasa Pandemik}

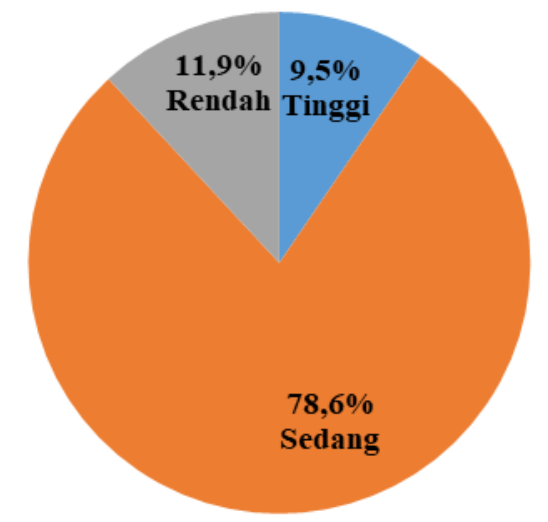

Gambar 2

Pie Chart Kesadaran Masyarakat dalam Meningkatkan Kesehatan dimasa Pandemik 


\section{Pembahasan}

Hasil analisis penelitian ini menunjukkan bahwa Kesadaran kesehatan pada setiap orang mungkin berbeda, terutama yang berkaitan dengan cara pandang dalam pola konsumsi makanan. Sehingga perlunya metode pendekatan dalam menyampaikan pengetahuan tentang pentingnya kesadaran kesehatan khususnya dalam pola konsumsi makanan yang alami dan sehat. (Kutresnaningdian \& Albari, 2012) .

Kesehatan sangat penting bagi manusia, karena tanpa kesehatan yang baik, setiap manusia akan sulit dalam melaksanakan aktivitasnya sehari-hari. Salah satu cara agar kesehatan tetap terjaga dengan baik adalah melalui olahraga (Prasetyo, 2013) Berdasarkan hal tersebut maka diperlukan perubahan perilaku baik dari tenaga kesehatan maupun dari masyarakat. Strategi perubahan perilaku adalah dengan memberikan informasi tentang cara menghindari penyakit dan meningkatkan pengetahuan masyarakat. Diharapkan dengan pengetahuan yang diperoleh tersebut dapat menimbulkan kesadaran di antara masyarakat untuk berperilaku sesuai dengan perilaku sehat (Prasetiya, 2015).

Pola hidup sehat adalah upaya seseorang untuk menjaga tubuhnya agar tetap sehat. Pola hidup sehat dapat dilakukan dengan cara mengkonsumsi makanan bergizi, olahraga secara rutin, dan istirahat yang cukup. perilaku hidup bersih dan sehat baik sebelum masa pandemi maupun selama pandemi covid 19 yakni dengan tetap berolahraga dan menjaga pola hidup bersih dan sehat. Jenis olahraga yang banyak dilakukan selama masa pandemi covid 19 dengan presentase tertinggi adalah Senam, Jogging dan Bersepeda. Sedangkan untuk aktivitas fisik di rumah dengan presentase tertinggi yang banyak dilakukan adalah membersihkan rumah dan memasak. Menerapkan pola hidup bersih dan sehat sudah seharusnya diterapkan oleh semua orang. Gerakan ini merupakan wujud perilaku yang baik karena merupakan langkah tepat dalam penanggulangan berbagai penyakit yang masuk ke dalam tubuh.(Ardiyanto et al., 2020)

\section{KESIMPULAN}

Berdasarkan penghitungan, analisis data. Hasil penelitian pada variabel tunggal yang telah diteliti dapat disimpulkan bahwa tingkat kesadaran masyarakat dalam meningkatkan kesehatan dimasa pandemik sebesar 78.8\% melebihi setengah nya, peningkatan kesehatan di masa pandemi ini dikarenakan pola konsumsi makanan yang alami dan sehat sehingga tingkat kesadaran masyarakat untuk sehat meningkat dimasa pandemi ini.

\section{DAFTAR PUSTAKA}

Ardiyanto, A., Purnamasari, V., Sukamto, S., \& Setianingsih, E. (2020). Analisis Perilaku Hidup Bersih dan Status Kebugaran Jasmani di Era Pandemi Covid-19 Dosen PGSD. 
Jendela Olahraga, 5(2), 131-140. https://doi.org/10.26877/jo.v5i2.6216

Arikunto, S. (2011). Prosedur Penelitian Suatu Pendekatan Praktik (14th ed.). Jakarta: Rineka Cipta.

AZWAR, S. (2017). Metode Penelitian Psikologi (2nd ed.). PUSTAKA PELAJAR.

Brier, J. (2020). MENINGKATKAN KESADARAN MASYARAKAT AKAN PENTINGNYA MENJAGA KESEHATAN MENTAL DENGAN MELAKUKAN AKTIFITAS FISIK PADA MASA PANDEMI. Malaysian Palm Oil Council (MPOC), 21(1), 1-9.

Dinda Mulyad, H. (2020). PENTINGNYA PENERAPAN PHBS DALAM MENGHADAPI PANDEMI COVID19 DI LINGKUNGAN MASYARAKAT.

Erliana, \& Sri, S. (2016). Kesehatan Masyarakat. شماره 89-117.

Giriwijoyo, S., Komariyah, L., \& Kartinah, N. T. (2007). Ilmu Kesehatan olahraga (Sports Medicine). Pendidikan Olahraga, 1-559.

Heni Hendrawati. (2016). Analisis Potensi Tenaga Kerja Lokal di Kawasan Bandara Internasional Jawa Barat (BIJB) di Kecamatan Kertajaya Kabupaten Majalengka. Pemakaian Bahasa Gaul Dalam Komunikasi Di Jejaring Sosial, 53(c), 25-38.

Kebiasaan Berperilaku Hidup Sehat Dan Nilai-Nilai Pendidikan Karakter. (2012). Jurnal Pendidikan Karakter, O(2), 189-201. https://doi.org/10.21831/jpk.v0i2.1303

Kutresnaningdian, F., \& Albari, A. (2012). Peran Kesadaran Kesehatan Dan Perhatian Pada Keamanan Makanan Terhadap Sikap Dan Minat Konsumen Dalam Membeli Makanan Organik. Jurnal Ilmu Manajemen, 2(1), 287461.

Muttaqien, K., Sugiarto, \& Sarifudin, S. (2019). Upaya meningkatkan kesadaran masyarakat terhadap kesehatan lingkungan melalui program bank sampah. Indonesian Journal of Adult and Community Education, 1(1), 6130

3 (2) 2021 | 120-131

Pane, B. S. (2015). Peranan Olahraga Dala: Kepada Masyarakat, 21(79), 1-4.

Prasanti, D. (2018). Penggunaan Media Komunikasi Bagi Remaja Perempuan Dalam Pencarian Informasi Kesehatan. LONTAR: Jurnal Ilmu Komunikasi, 6(1), 13-21. https://doi.org/10.30656/lontar.v6i1.645

Prasetiya, C. H. (2015). Efektifitas pendidikan kesehatan terhadap peningkatan pengetahuan keluarga tentang hipertensi. Journal of Mutiara Medika, 15(1), 67-74.

Prasetyo, Y. (2013). KESADARAN MASYARAKAT BEROLAHRAGA UNTUK PENINGKATAN KESEHATAN DAN PEMBANGUNAN NASIONAL Oleh: Yudik Prasetyo Dosen Jurusan Pendidikan Kesehatan dan Rekreasi FIK UNY. Kesadaran Masyarakat Berolahraga Untuk Peningkatan Kesehatan Dan Pembangunan Nasional, VOL.XI, 219-228.

Sugiyono. (2014). Metode Penelitian Kuantitatif, Kualitatif dan $R \& D$ (21st ed.). Bandung: Alfabeta.

Surahman, \& Supardi Sudibyo. (2016). Ilmu Kesehatan Masyarakat PKM. شماره 8; 99-117.

Wicaksono, A. (2020). Aktivitas Fisik Yang Aman Pada Masa Pandemi Covid-19. Jurnal Ilmu 
Journal of Physical and Outdoor Education, 3 (2) 2021 | 120-131

ISSN : 2721-9992 (Online)

ISSN : 2656-1883 (Print)

Keolahragaan Undiksha, 8, 10-15.

Yuliana. (2020). Olahraga yang Aman di Masa Pandemi COVID-19 untuk Meningkatkan Imunitas Tubuh. Bali Membangun Bali, 1, 103-109.

\} 